\title{
THE EFFECT OF VIRAL MARKETING ON PURCHASE DECISION WITH CUSTOMER TRUST AS INTERVENING VARIABLE
}

\author{
Rio Garia Aprillio', Arry Widodo ${ }^{2}$ \\ Universitas Telkom, Indonesia \\ riogarlio@gmail.com ${ }^{1}$, arrywie@telkomuniversity.ac.id²
}

\begin{abstract}
The study aims to determine the level of influence of viral marketing on purchasing decisions through customer trust in favehotel Hyper Square Bandung. The condition shows more eagerness on their business, the more enhancement on its services. The variables in this study are viral marketing as an independent variable, purchasing decision as a dependent variable, and customer trust as an intervening variable. The used method of this study was a quantitative method with the type of research of descriptive associative with a sample of 400 respondents. The used sampling technique in this study was non-probability sampling. The used methods of data analysis in this research were descriptive analysis method and structural equation modeling (SEM). Data processing was performed by using SmartPLS 3.0 software for Windows. Research Result: (1) Viral marketing variable (X) has an influence significant with intervening variables of customer trust $(Z)$. (2) The effect of intervening variable customer trust (Z)hasn an influence significant on purchase decision (Y). (3) The effect of viral marketing $(X)$ has an influence significant on purchase decision $(Y)$. (4) The indirect effect between viral marketing $(X)$ and purchase decision $(Y)$ through intervening variable customer trust $(Z)$ has a positive indirect effect of 0.296 and t-statistics value of 9.950> 1.96, which means significant.
\end{abstract}

Keywords: Viral Marketing, Purchase Decision, Customer Trust

\section{INTRODUCTION}

Indonesia defines as the country with rich of charms. Many tourism areas with international attraction potential are located in Indonesia. Moreover, the varying tourism area within Sabang to Merauke forms the uniqueness of Indonesia. Speaking of tourism in Indonesia, every tourism areas in Indonesia began to apply Sapta Pesona, which includes security, order, cleanliness, coolness, beauty, hospitality, and memories. Besides the Indonesian should also have a tourism awareness that has an impact on improving the regional economy. It is shown by the development of hotels, resorts, souvenirs shops, and local special cuisine restaurants.

The denial of Bandung has become one of the favorable destinations visited by many tourists both domestic and abroad could not be supported. It happens as Bandung contains the diver's tourism experience. Bandung has been popular with its creativity and productivity in various business activities in tourism. Bandung is known as one of the tourist-friendly city. The data from the Central Statistics Agency (BPS) of Bandung show that tourist arrivals in 2016 reached 5.000.625 individuals supports the data on Bandung as a tourist-friendly city, 173.036 for foreign tourists, and 4.827.589 for domestic tourists.domestik.

Table 1. The number of Hotel in Bandung from 2012 to 2016

\begin{tabular}{cc}
\hline Year & Number of Hotel \\
\hline 2012 & 301 \\
2013 & 328 \\
2014 & 331 \\
2015 & 334 \\
2016 & 336 \\
\hline Source: West Java Central Statistics \\
\multicolumn{2}{c}{ Agency (2020) }
\end{tabular}

Based on the table above, it can be seen that the growth of hotels in Bandung has increased every year. It 
proves that the level of competition between hotels in Bandung is quite tight. Therefore, more entrepreneurs are competing for entering the lodging services industry. Lodging service industry developer increasingly competes by creating a sustainable competitive advantage to face this competition. The phenomenon is conducted for the company could survive and develop in the future.

Table 2. Internet User in Indonesia

\begin{tabular}{cc}
\hline Tahun & Number of Users \\
\hline 2016 & $132,7 \mathrm{M}$ (Equivalent to $51,7 \%$ of Population) \\
2017 & 143,26 Juta (Equivalent to $54,7 \%$ of Population) \\
2018 & 171,18 Juta (Equivalent to $64,8 \%$ of Population) \\
\hline & Source: Apjii (2019)
\end{tabular}

The condition proves that internet users in Indonesia continue to escalate every year. It also proves that Indonesian have been accepting the presence of the Internet. The dissemination of information is varying from Facebook, Twitter, Instagram, and other social media. The purpose of using the internet in Indonesia varies from chatting, sending pictures, giving comments on a particular product, to marketing a business for free.

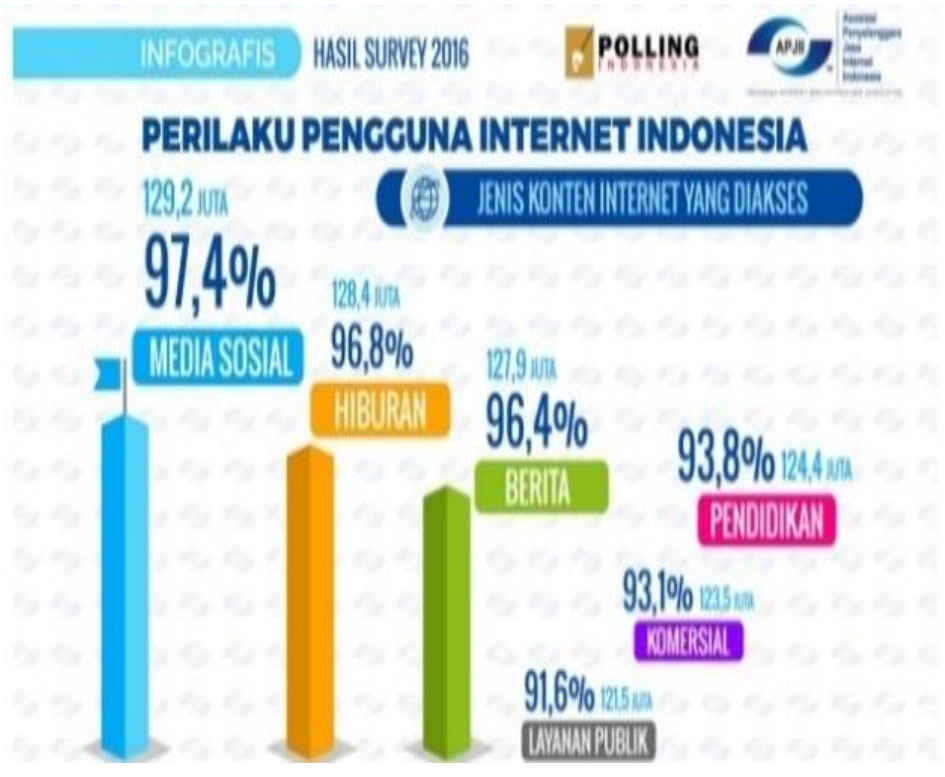

Figure 1. The Data of Internet User based on the Accessed Content Source: Apjii (2016)

Figure 1 shows the survey results of internet user statistics in Indonesia made by the Association of Indonesian Internet Service Providers in 2016. It states that the number of social media users in 2016 reached 129.2 million or $97 \%$. The data in Figure 1.6 shows the high use of the internet especially social media triggering the spread of information through social media. Social media users could freely edit, add, modify the text, images, videos, and various other content. There are various types of social media such as Twitter, Facebook, Instagram, Google+, Linked, Youtube, and many more. It means that social media is the right media to spread information as it has the largest 
percentage of internet user behavior in Indonesia.

Helm (2000) in Yessy et al (2019) identifies Viral Marketing as a concept of communication and distribution that relies on customers to send digital marketing messages of products through electronic messages to other potential customers in their social scope. It also makes these potential customers send messages on the same product. Viral marketing develops through the internet, which duplicates itself more and more, similar to the work of a computer virus. Viral marketing works by spreading information through a database of registered internet users for mass use from free electronic websites such as Yahoo, Hotmail, and Gmail. Those internet websites provide free email services and offer various product offers along with the e-mail service. The initial process of Viral Marketing could begin from various parties even from the company. Information on this product must come from parties who are direct consumers or from parties who are having great individuals for influencing others similarly like travel communities or travel vloggers or related to products. Thus, the offered product information will be more effectively accepted by consumers.

The object under the study also conducted some viral marketing through the official Instagram of favehotel Hyper Square Bandung under the username @favehypersquare, which collaborated with several influencing accounts and media partners to disseminate information on products and events such as hotel blogger accounts and influencing account of @hotelopedia, @fazatraveldiary, @reviewhotelresto, @abdillahhw, @herman.oey, @whatsnewbandung_, @rikaekawati, and many more. Moreover, favehotel Hyper Square conducts email blast which means that information is distributed to many consumers using a database. Favehotel Hyper Square also invites hotel reviewers to assess the quality of products and services that will be conveyed through online travel sites, which means this is word of mouth through the internet media. It purposes to influence other people who read the information for believing and finally staying at favehotel Hyper Square Bandung short term or long term.

Trust defines as the belief of one party regarding the intentions and behavior aimed at the other party. Thus, consumer confidence defines as the expectation of consumer expectation on service providers are trusted or relied upon to fulfill their promises (Siagian \& Cahyono, 2014). Meanwhile, Romdonah (2015) infers that Purchase Decision defines as a decision-making process of purchase, which includes determining what will be purchased or leave out through the decision from previous activities.

Based on the problems faced by consumers related to trust in the information provided through social media of Instagram that spreads through Viral Marketing, it may influence consumer purchasing decisions that reviewing information from reliable sources. Based on the description above, the researcher is interested in conducting a manuscript under the title of The Effect of Viral Marketing on Purchase Decision with Customer Trust as an Intervening Variable on Favehotel Hyper Square Bandung.

\section{METHODS}

Based on the variables, the quantitative method will be used in this study, where researchers will compare the reality of the topic raised with existing theories. A descriptive study is used in the study as the type of research based on the research objectives.

This study used using the ordinal scale. According to Indrawati (2015) defines the ordinal scale as a scale, which is not only classifying an existing variable but also provides the ranking between categories.

The population in this study is the customer who has stayed at favehotel Hyper Square Bandung. The sample 
used was 400 respondents taken from favehotel Hyper Square customers who have stayed over the age of 17 years. The reason for choosing the criteria above the age of 17 years is based on the respondent's assumption that the respondent could be independent in providing answers. Moreover, it is also following the conditions of staying in a hotel, which requires Identity Card.

The data analysis technique was Structural Equation Modeling (SEM). (Santosa, 2018) states that structural equation modeling (SEM) is a statistical method used by researchers in various fields, such as social-behavioral, education, biology, economy, medical, and marketing researches.

\section{RESULTS AND DISCUSSION}

The analyzed variable in this study is: (1) Viral Marketing (X); (2) Purchase Decision (Y); (3) The Intervening Variable is Customer Trust (Z). This study conducted the process of data description both qualitatively and quantitatively for depicting the quality of each variable.

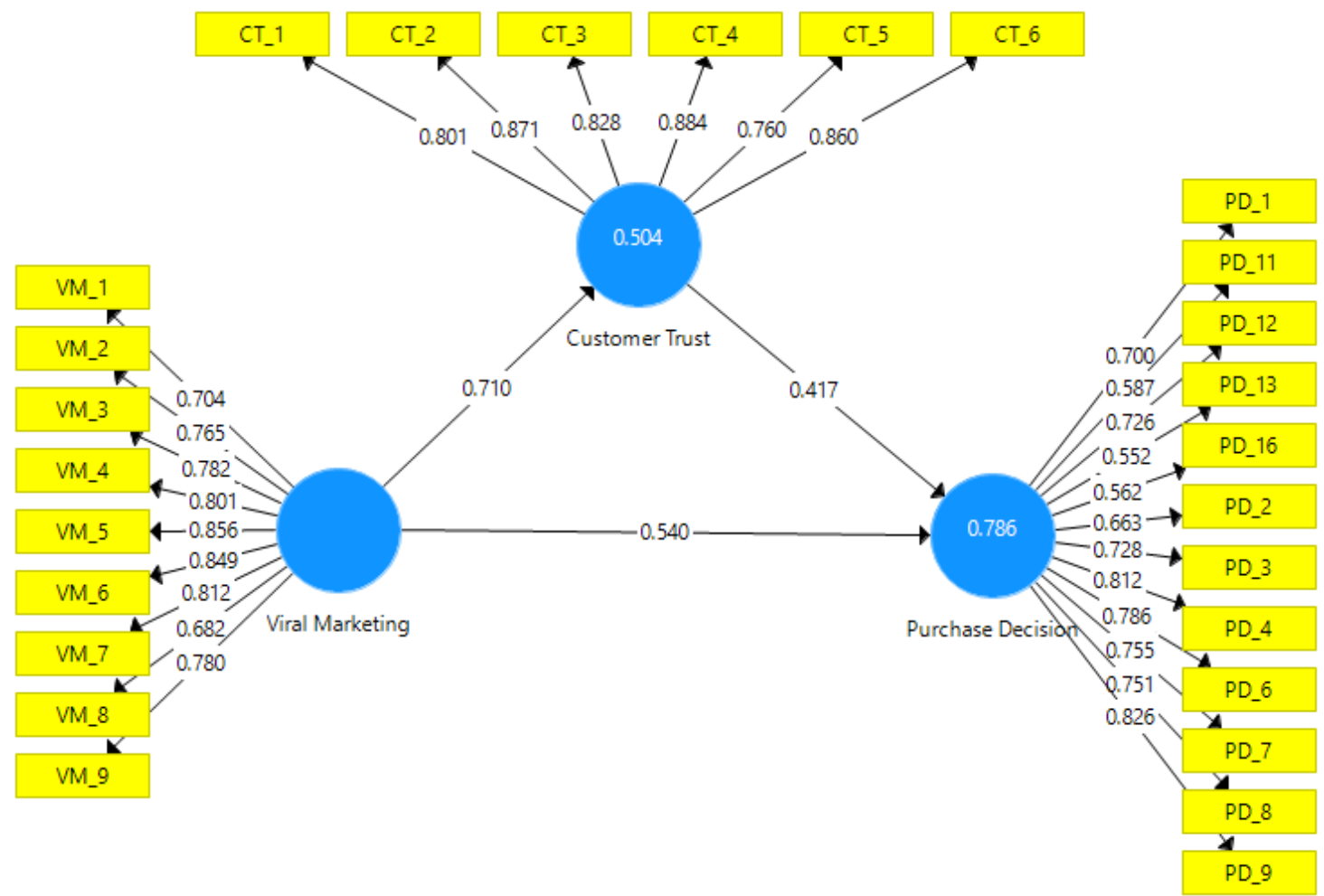

Figure 2. The Result of Outer Model

Source: The Result of Data Analysis from SmartPLS 3.0 (2020)

Table 3. The Value of Convergent Validity

\begin{tabular}{cccc}
\hline Variable & AVE & Critical Value & Model Evaluation \\
\hline Viral Marketing $(\mathrm{X})$ & 0,613 & $>0,5$ & Valid \\
Purchase Decision $(\mathrm{Y})$ & 0,504 & & Valid \\
Customer Trust $(\mathrm{Y})$ & 0,698 & & Valid \\
\hline
\end{tabular}

Source: The Result of Data Analysis from SmartPLS 3.0 (2020)

In the construct validity test, in general, it can be measured by loading score parameters and using AVE parameters. AVE score must be> 0.5 and for loading scores must be> 0.5 . If the loading score $<0.5$ this indicator can 
be removed from the construct because this indicator is not loaded into the construct that represents. However, if the loading score is between $0.5-0.7$, the researcher should not delete the indicator that has the loading as long as the AVE score for the indicator is $>0.5$ (Abdillah \& Hartono, 2015).

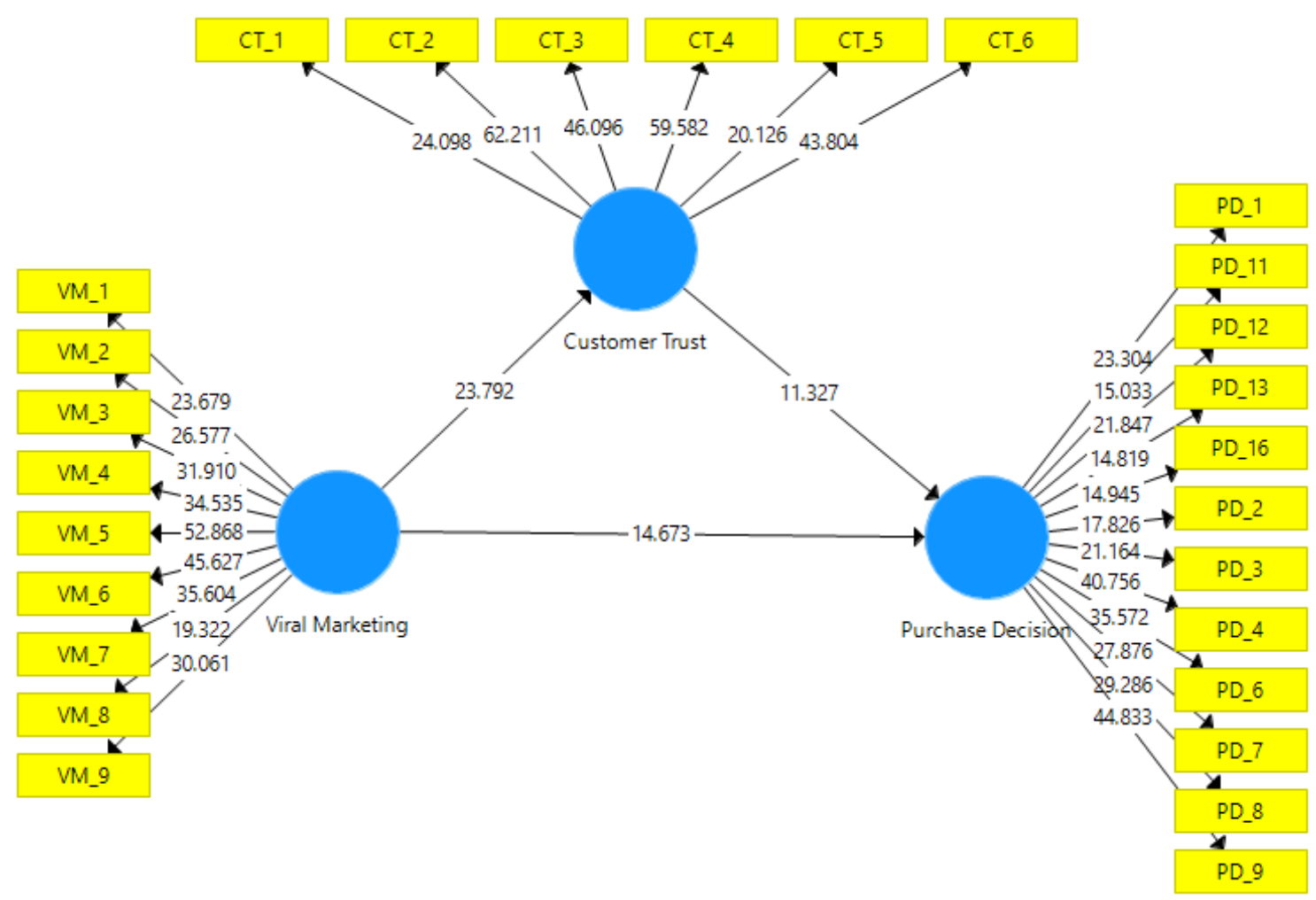

Figure 3. The Model of Path Diagram Inner (Bootstrapping)

Source: The Result of Data Analysis from SmartPLS 3.0 (2020)

Table 4. The Value of $R$-Square

\begin{tabular}{cc}
\hline Variable & $\mathbf{R}^{2}$ \\
\hline Purchase Decision & 0,786 \\
Customer Trust & 0,504
\end{tabular}

Source: The Result of Data Analysis from SmartPLS 3.0 (2020)

Table 4 shows that the R-square value of the customer trust variable is 0.504 . It means that the changes in the variation of customer trust variable could be explained by the viral marketing variable at $50.4 \%$, while the remaining
$49.6 \%$ is explained by other variables excluded from this study. The value on other variables is considered moderate as it reached above 0.33. Furthermore, the R-square value of the purchase decision variable is 0.786 , meaning that the variation in the change in the purchase decision variable can be explained by a viral marketing variable of $78.6 \%$, while the remaining $21.4 \%$ is explained by other variables excluded from this study. The value is considered as moderate as it reached above 0.33. 
Table 5. Hypotheses Testing

\begin{tabular}{cccccc}
\hline & $\begin{array}{c}\text { Original } \\
\text { Sample (O) }\end{array}$ & $\begin{array}{c}\text { Sample } \\
\text { Mean (M) }\end{array}$ & $\begin{array}{c}\text { Standar } \\
\text { Deviation } \\
\text { (STDEV) }\end{array}$ & $\begin{array}{c}\text { T-Statistics } \\
(\text { (O/STDEV) }\end{array}$ & $\begin{array}{c}\text { P } \\
\text { Values }\end{array}$ \\
\hline $\begin{array}{c}\text { Viral Marketing -> Customer } \\
\text { Trust }\end{array}$ & 0,710 & 0,712 & 0,030 & 23,792 & 0,000 \\
$\begin{array}{c}\text { Customer Trust -> Purchase } \\
\text { Decision }\end{array}$ & 0,417 & 0,420 & 0,037 & 11,327 & 0,000 \\
$\begin{array}{c}\text { Viral Marketing -> Purchase } \\
\text { Decision }\end{array}$ & 0,540 & 0,538 & 0,037 & 14,673 & 0,000 \\
$\begin{array}{c}\text { Viral Marketing -> Purchase } \\
\text { Decision (Indirectly through } \\
\text { customer trust) }\end{array}$ & 0,296 & 0,299 & 0,030 & 9,950 & 0,000 \\
\hline
\end{tabular}

Source: The Data Analysis from SmartPLS 3.0 (2020)

The result of the study depicts the effect of viral marketing on customer trust, and its positive result may be seen in Table 5 with the value of positive path coefficients of 0.710 . The t-statistics shows the value of $23.792>1.96$, which means significant. Thus, $\mathrm{H}_{1}$ in this study was accepted and $\mathrm{H}_{0}$ was rejected.

Another result of the study shows the influence of customer trust towards purchase decisions, which could be seen in Table 5. The result obtains the value of positive path coefficients with 0.417 . The t-statistics achieved a value of $11.332>1.96$, which means significant. Therefore, $\mathrm{H}_{2}$ in this study is accepted and $\mathrm{H}_{0}$ is rejected.

The result of the effect of viral marketing towards purchase decisions could be seen in table 5 . It obtained positive path coefficients of 0.540 and tstatistics of $14.673>1.96$, which means significant. Hence, $\mathrm{H}_{3}$ in this study was accepted and $\mathrm{H}_{0}$ was rejected.

The indirect effect between viral marketing towards purchase decisions through customer trust can be seen in Table 5. The result obtained a positive indirect effect of 0.296 and at-statistics value of $9.950>1.96$, which means significant. Thus, $\mathrm{H}_{4}$ in this study was accepted and $\mathrm{H}_{0}$ was rejected.

\section{CONCLUSION}

Based on the results of research and analysis that has been conducted, some conclusions are obtained for answering the problems formulated in this study, which are as follows:

The results show that Viral Marketing is classified in the category of good. Also, there are positive and significant influences that show the relationship between Viral Marketing and Customer Trust. The results show that the Purchase Decision is classified as quite good. Also, there are positive and significant influences that indicate a relationship between the Customer Trust and the Purchase Decision. The results show that Customer Trust is classified in the category of good. In addition, there are positive and significant influences that indicate a relationship between Viral Marketing and Purchase Decisions. Viral Marketing has an indirect positive and significant effect on Purchase Decisions through Customer Trust at favehotel Hyper Square Bandung.

\section{REFERENCES}

Abdillah, W., \& Hartono. (2015). Partial Least Square (PLS). Andi.

Apjii. (2016). Periaku Pengguna Internet 
Indonesia.

Penyelenggara Jasa Internet Indonesia.

Apjii. (2019). Internet User in Indonesia. Asosiasi Penyelenggara Jasa Internet Indonesia. apjii.or.id

Indrawati. (2015). Metode Penelitian Manajemen dan Bisnis Konvergensi. Teknologi Komunikasi dan Informasi. Aditama.

Romdonah, R. (2015). Pengaruh Inovasi Produk, Harga, dan Citra merek Terhadap Keputusan Pembelian Sepeda Motor Honda Beat (Studi Pada Konsumen Dealer Honda Pratama Kurnia Kasih).
Santosa, P. I. (2018). Metode Penelitian Kuantitatif: Pengembangan Hipotesis dan. Pengujiannya Menggunakan SmartPLS. Andi.

Siagian, H., \& Cahyono, E. (2014). Analisis Website Quality, Trust, dan Loyalty Pelanggan Online Shop. Jurnal Manajemen Pemasaran, 8(2).

Yessy, A., Prasetyo, F. H., \& Sulistyowati, R. (2019). How Social Media Marketing Influences Online Purchasing Decision: Study of the Viral Marketing and Perceived Ease of Use. KnE Social Sciences. 